\title{
3. 喉頭全摘と機能外科
}

天津 睦郎 (神戸大学・耳鼻咽喉科)

\section{はじめに}

喉頭の機能には, 呼吸, 嚥下時の下気道の保護, 発声 の3つがある。喉頭全摘（喉摘）を行うと, 気管切断端 が頝部下方正中で皮膚と縫着され，下気道と上気道が分 離する。乙の結果, 自然道での呼吸と発声が不可能とな

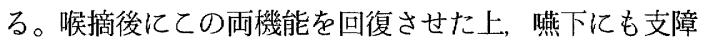
をきたさない手術方法の開発が喉摘後の機能外科の理想 と言える。ところで, 現時点までの喉摘後の機能外科は， もっぱら音声の回復に主眼をおいたもので，数多くの方 法か溌表されている。これらの方法のほとんどは，喉摘 後に気道と上部消化管すなわち食道または咽頭の間に連 絡路（シャント）を形成し，呼気により上部消化管の粘 膜を振動させるととを基本理念としている。

一方，てのシャントを通過する呼気により音声を再獲 得できるかわりに，シャントの存在により嶼下時に液状 物が気道内に流入 (誤䓵) する危険が生じる。先述の機 構により喉摘後に音声を再獲得できることは疑う必要の ない事実である。そてで，音声と引き換えに誤罴を生じ させないための工夫が是非とも必要となる。

著者は, 1976年以降喉摘後の音声再獲得のために気管 膜様部を開いた気管食道㜢造設術（T E shunt）を行っ

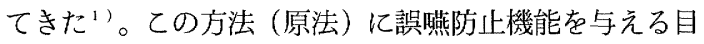
的で，1983年以後食道筋肉弁を用いたととろ，ほほ予期 した成果を挙げることができだ2。

本論文では, 著者の行っている誤㺞防止術式を含む音 声再獲得術につき述べる。

\section{手術術式}

\section{1. 気切・喉摘}

第 3，4 気管輪で開息し，挿管麻瘏を行う。挿管チュー ブは換気に差し支えなければ，細めのもののほうがのち の手術を容易にする。皮切はU皮切のほうが, 縦皮切上 り望ましい。頝部部清術を併用する時は，その側の皮切 を外側寄りとし，上方は乳突先端まで延長する。

術中，甲状腺を下方から上方に向けて気管および食道 から剥離挙上しておく。乙の際，上甲状腺動脈は栄養血 管として保存する。喉摘は通常, 第 1 気管輪と輪状軟骨 の間で行う。気管は第 2 気管輪位までの切除はかまわな いが，それより下方での切除は次項で述べる気管弁の確 保江困難を生じる。

喉摘の際の注意点として, 気管後壁と食道前壁の間を 剶離しないとと，および気管膜様部をできるだけ無駄に

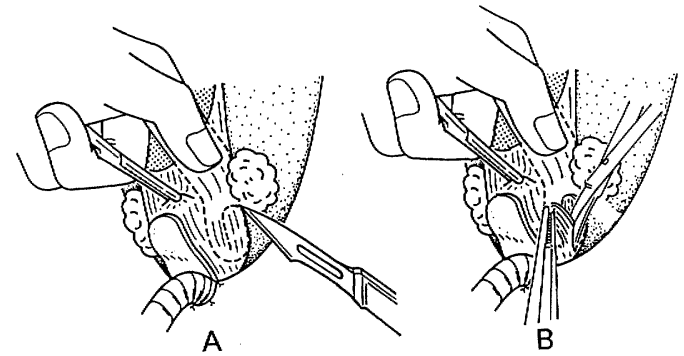

図 1 食道筋肉弁の作成 図 1-Aのように気管弁中央の高さで食道側後壁にト リミングを行い, 先端をピンセットで助手につかま せ粘膜下に剶離し，1-Bのように下方有茎の食道筋 肉弁老得る。

しないこと,が重要である。

\section{2. 気管弁の作成}

下方有茎の気管膜様部弁を作成する。気管軟骨の 4 , 5 輪分に相当する膜様部を用いる。気管弁の幅が狭いと 思われる場合は，予め膜様部の外側に軟骨輪を残してお き，乙の部の粘膜を剝離して用いる。気管弁は長さ 3 $\mathrm{cm}$, 幅 $1.5 \mathrm{~cm}$ 位でよい。気管弁を得たら, 気管孔の下 半部を形成しておくと以後の手術操作か洝定して行える。

3. 食道筋肉弁の作成

術者は，患者の右側住立つ。モスキート鉜子で気管弁 直上の食道筋層をしっかりとつまんで, 咽頭欠陥部から 左示指頭を食道内に入れ，母指と示指でこのモスキート 銝子を固定するように把持する。左示指頭は, 気管弁の 中央の高さで食道側後壁が緊張するように挿入する。乙 の部加下方有茎の食道筋肉弁を得る。

まづ, 図1-A のようにトリミングをしたのち，ての 先端を助手にピンセットでつまませ, 図1-B のように 筋層を粘膜下で剝離する。鋏の先で食道内の左示指頭を 触れながら行えば粘膜を破ることはない。この食道筋肉 弁は左右対称纪両側から得る。大きさは, 長さ $1.5 \mathrm{~cm}$, 幅 $0.7 \sim 8 \mathrm{~cm}$ 位でよい。乙のあと, 食道筋肉弁の先端 同志を合わせて長さが充分かどうか確認しておく。食道 筋肉弁か洵管弁中央の高さより上方かつ前方から採取さ れた場合は，誤曣防止の㗢きが著しく低下するので注意 を要する。

4. 側々吻合部の作成

モスキート鈷子で，気管弁直上の食道筋層をしっかり とつまんで, 咽頭欠陥部から左示指頭を食道内に入れる。 

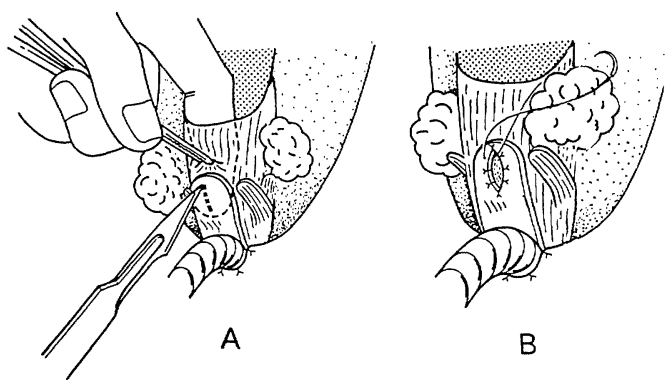

図 2 側々吻合部の作成

気管弁の上縁直下に0.7 $1 \mathrm{~cm}$ の縦切開を入れ, 食道 内に入る。食道粘膜の切開縁を気管弁のそれに8 針 ていねいに縫着する

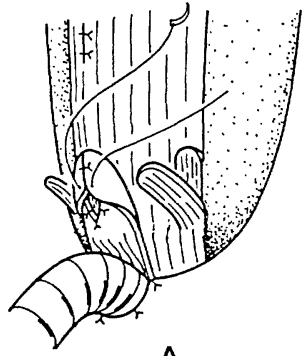

A

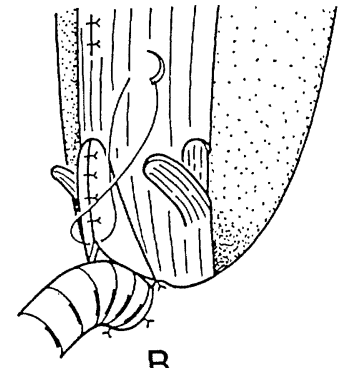

$\mathrm{B}$
図 $3 \mathrm{TE}$ シャレト

気管弁の左右縁を, 上縁より粘膜下に縫着する (図3-A)。気管孔のでき上りを想定して縫着を やめる（図 3-B）

この要領は食道筋肉弁を採取する時のそれと同様である。 左示指頭は気管弁上縁直下の食道内にくるようにする。

気管弁の上縁直下に 11 番の先刃刀を用いて，正中に 0. 7 1 cm の縦切開を入れる (図 2-A)。乙の際, 食道 内の左示指頭で先刃刀の先を感じながら切開を進めると よい。いよい上食道粘膜直前に達したら, 粘膜を慎重に 切開し，切開縁を見失うことがないようにする。そのた めに，切開縁の上下左右 4 力所在モスキート鉗子でつま んでおくとよい。

気管弁の粘膜切開縁と食道粘膜のそれとをてい杍いに 縫着する。まず, 上下 2 力所, ついで左右 3 力所, 計 8 針縫合する（図 2-B）。縫合糸は吸収性のものを使う。 術後にシャントの狭窄ないし, 閉塞がおこるとしたら, ての部以外にはないので，ていねいに縫着する必要があ る。

\section{5. 咽頭縫合}

縦 1 本の粘膜縫合は術後に pseudovallecula つまり ポケットを生じ，㺞下が円滑に行われないととがある。 TまたはY 字型の縫合がよい。下咽頭収縮筋の強固な縫 合は術後の発声に際し, 力みを必要とし, せっかくシャ ントが開存しているのに発声が不能になるてとすらある。 したがって，照射後の症例で創傷の治療機転に問題がな
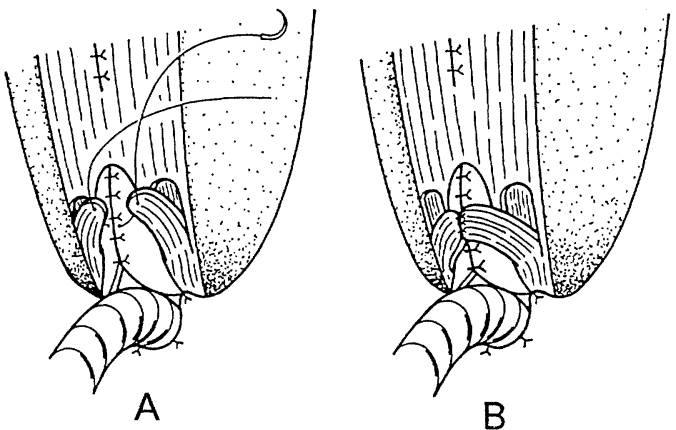

図 4 食道筋肉弁をシャントの前面で縫着 $\mathrm{A}, \mathrm{B}$ のように両食道筋肉弁の先端をシャントの前 面で縫着する。最始の 1 針はシャントの前面を含め て縫着する

る場合を除いて，筋層の縫合はできれば最小限にするの がよい。

6. TEシャントの造設

気管弁の上縁より，その左右縁を粘膜下汇縫着する (図 3-A)。気管孔のでき上がりを想定して縫着をやめる (図 3-B)。縫合糸は吸収性のものを用いる。

7. 両側食道筋肉弁をシャントの前面で縫着

TEシャントの造設が終わったら，図 4-A. Bのよう に食道筋肉弁の先端同志をシャントの前面で 3 針縫着す る。最初の 1 針はシャントの前面を含めて縫着する。縫 合糸はやはり吸収性のものを用いる。

8. 皮膚縫合

死腔を生じないよう suction drain を入れ，気管孔 上縁を形成し，皮膚縫合を行って手術を終了する。

術後管理と発声

術後管理は通常の喉摘と全く同じである。発声は創の 状態をみて，少なくとも2 週以後に行う。気管孔を指で 閉鎖して発声を命じる。

おわりに

喉摘後の機能外科として，著者の行っている音声獲得 手術につき述べた。手術的に音声を獲得させることは決 して難しいととではない。音声と引き換えに誤燕を生じ させない土夫と努力が必要と言える。

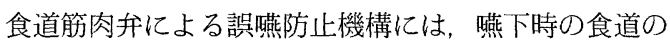
拡張と挙上が大きく関与していると考えられる。すなわ ち，燕下に際し食道の前面にあるシャントは食道の拡張 と挙上が抢てる際，食道筋肉弁により締めつけられるた めにシャントを通じて食道内容か洵道流入するのが防 止されるからである。

以前には，上方有茎の食道筋肉弁を用いた方法を報告 したが，その後下方有茎の食道筋肉弁を用いることにし た。その理由は，誤嶼防止を確実にするためには食道筋 肉弁が食道の側後壁から採取されることのほかに, シャ

110 手術手技研究会〔 I ] 喉頭癌に対する機能外科 
ントに直交する必要があると考えたからである。食道筋 肉弁がシャントと直交するためには，局所の状況から考 えて，下方有茎の方が上方有茎より確実性に富むことが わかったからである。
文献

1) 天津睦郎, 松居敏夫, 牧 孝, 他: 喉摘後の音声 獲得手術一 One stage で行う新しい術式について 日耳鼻。 80：709-785，1977.

2) Amatsu, M. , Makino, K., Kinishi, M. et al: Primary tracheosesophageal shuntoperation for postlaryngectomy speech with sphincter mechanism, Ann Otol Rhinol Laryngol, 95 : 373-376, 1986. 